\title{
II．二次性心筋症を見逃さない
}

\section{2. 心サルコイドーシス}

\section{手塚 大介12) 磯部 光章3)}

要旨

サルコイドーシスの診断ガイドラインには 2006 年に策定された日本サルコイドーシス/肉芽腫性疾患学 会によるものと厚生労働省の特定疾患の呼吸器系疾患調查研究班（びまん性肺疾患）の策定した認定基準 とある. 心内膜下生検や血液バイオマーカー, 画像診断により診断するが, 最近FDG-PET, 心臓MRIの有 用性が報告されている。また新しい疾患概念として孤発性心サルコイドーシス症が注目されている。治療 は薬物療法としてはステロイドが主であり, ペースメーカー療法やICD (implantable cardioverter defibrillator）などデバイス治療も行われる.

[日内会誌 $103: 299 \sim 308,2014$ ]

Key words 画像診断, ステロイド治療, 心臓デバイス治療, 孤発性心サルコイドーシス

はじめに

サルコイドーシスは全身性に生じる肉芽腫性 疾患で, 病理像では炎症細胞の浸潤と非乾酪性 類上皮細胞肉芽腫が特徴である ${ }^{1)}$.

診断ガイドラインとして, 2006 年に策定され た日本サルコイドーシス/肉芽腫性疾患学会によ る診断基準 ${ }^{1)}$ と厚生労働省の特定疾患の呼吸器系 疾患調査研究班（びまん性肺疾患）の策定した 認定基準 ${ }^{2)}$ とる. 非乾酪性肉芽腫を組織学的に 確認することが診断の基本となっているが, 心 サルコイドーシスにおいては心筋生検の感度は
20〜30\%と低く, 診断に苦慮するケースが少な からず存在する ${ }^{3)}$.

心サルコイドーシス症を発症すると完全房室 ブロックや心室頻拍の出現により患者の予後に 大きく影響する。 心内デバイスの発達により致 死性不整脈の二次予防に対する治療成績は向上 している. その一方で発症後心機能が低下して いくケースもあり, 薬物治療としてステロイド 薬や免疫抑制薬が用いられる.

\footnotetext{
1) 東京医科歯科大学附属病院循環器内科, 2) 東京大学大学院先端臨床医学開発講座, 3) 東京医科歯科大学大学院循環制御 内科学

Cardiomyopathy : Progress in Diagnosis and Treatments. Topics : II. Secondary Cardiomyopathy ; 2. Cardiac sarcoidosis. Daisuke Tezuka ${ }^{12)}$ and Mitsuaki Isobe ${ }^{3)}:{ }^{1)}$ Department of Cardiovascular Medicine, Tokyo Medical and Dental University, Japan, ${ }^{2)}$ Department of Advanced Clinical Science and Therapeutics, The University of Tokyo, Japan and ${ }^{3)}$ Department of Cardiovascular Medicine, Tokyo Medical and Dental University, Japan.
} 
表 1. 心臓病変を強く示唆する臨床所見

（1）主徵候
(a) 高度房室ブロック
(b) 心室中隔基部の菲薄化
(c) Gaシンチでの心臓への異常集積
(d) 左室収縮不全 $(E F<50 \%)$

(2) 副徵候

（a）心電図異常：心室不整脈，右脚ブロック，軸偏位，異常Q波のいずれか

（b）心工コ一：局所的な壁運動異常or形態異常（心室瘤，心室壁肥厚）

（c）心筋シンチ $(201 \mathrm{TICl}, 99 \mathrm{mTC}-\mathrm{MIBI}, 99 \mathrm{mTC}$-tetrofosmin) での灌流異常

（d）Gd造影MRIにおける心筋遅延造影所見

（e）心內膜心筋生検：中等度以上の心筋間質の線維化や単核細胞浸潤

主徴候中 2 項目以上, もしくは主徵候 1 項目かつ副徴候 2 項目以上で陽性の場合を 心臟病変を強く示唆する所見という.

一「サルコイドーシスの診断基準と診断の手引き」日サ会誌 2006, 26（1）より引用・ 改変一

表 1 付表. 心サルコイドーシスの診断の手引き

\begin{tabular}{|c|c|c|c|c|c|c|}
\hline & $\begin{array}{c}\text { 心臓病理 } \\
\text { 肉芽腫 }\end{array}$ & $\begin{array}{l}\text { 他臟器での } \\
\text { サ症の診断 }\end{array}$ & & & & \\
\hline 組織診断群 & + & & & & & 心サ症 \\
\hline \multirow{5}{*}{ 臨床診断群 } & \multirow{5}{*}{-} & & \multirow{2}{*}{$\begin{array}{c}\text { 基本診断基準 } \\
\text { (6 項目) }\end{array}$} & \multicolumn{2}{|c|}{ 心臓所見 } & \\
\hline & & & & $\begin{array}{c}\text { 主徵候 } \\
\text { (4 項目) }\end{array}$ & $\begin{array}{l}\text { 副徵候 } \\
\text { (5 項目) }\end{array}$ & \\
\hline & & \multirow{2}{*}{+} & \multirow{2}{*}{$2 \leqq$} & $2 \leqq$ & O & \multirow{2}{*}{ 心サ症 } \\
\hline & & & & 1 & $2 \leqq$ & \\
\hline & & \multicolumn{4}{|l|}{-} & $\begin{array}{c}\text { 診断 } \\
\text { できない }\end{array}$ \\
\hline
\end{tabular}

※サ症 : サルコイドーシス, 心サ症 : 心サルコイドーシス

\section{1. 心サルコイドーシスの診断について}

\section{1）現行のガイドラインによる診断}

日本サルコイドーシス/肉芽腫性疾患学会によ る 2006 年の診断基準によると, 心サルコイドー シスの診断は表 1 , 表 2 に掲げる診断項目からな る. 表 2 の項目によれば, 一つの臓器で組織学 的診断が得られた上で, その他の臓器で組織学 的診断または臨床診断が得られるか, 全身反応 を示唆する所見が得られれば, 組織診断群とな る. 組織学的診断が得られない場合は, 二つ以
上の臓器で臨床所見を認め, 全身反応を示唆す る所見が得られれば臨床診断群の要件を満たす. すなわち，心サルコイドーシスと診断するには 心臓か他の臓器の組織学的診断が必須であり, 組織学的診断が得られない場合は, 心臓を含む 複数臓器での臨床診断が必須である (表 1 , 付表).

このため心内膜下生検により非乾酪性類上皮 細胞肉芽腫が確認された場合は他臓器所見など があれば心サルコイドーシスの診断が可能とな る一方で, 心臓で組織学的診断が得られない場 合, 心サルコイドーシスの診断は特に困難となる. 
表 2. サルコイドーシスガイドライン

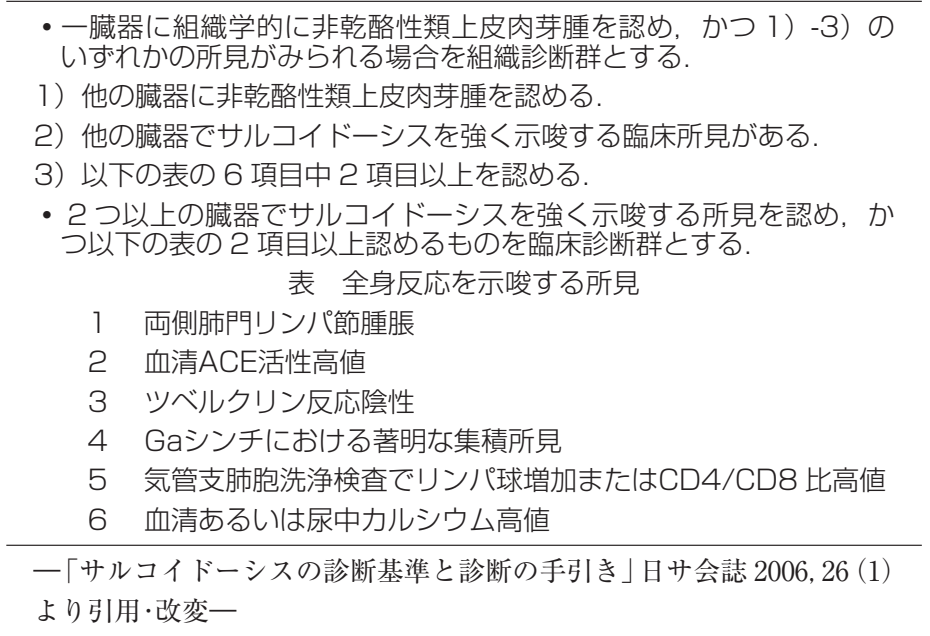

\section{2）心筋生検による診断について}

心内膜下生検による非乾酪性類上皮肉芽腫の 確認があり，他の肉芽腫性疾患を除外できてい れば, 心サルコイドーシスと診断しても認容さ れる. しかし，生検はサンプリングエラーや心 筋生検の手技に種々の制約があり, その感度は 20〜30\% と低い3).

サルコイドは右室には確認される頻度が少な く, 比較的左室に分布する ${ }^{4}$. 最近は左室からも 生検が行われるものの, 従来右室での生検が一 般的であった。 また心筋のサルコイドは不均一 でpatchyであり, その後消退するか線維化・瘏 痕となり, 検查の感度は施行時の心サルコイドー シスの病期・病勢に影響を受ける ${ }^{4,5)}$. サルコイ ドが検出されず間質の線維化所見などに留まる ことはよく経験されることである ${ }^{6}$. カテーテル 自体の操作性はそしく, 微小でpatchyなサルコ イドに当たる確度も少ない. 心筋生検による感 度を高めるためには, 標本数を多くする, 画像 によるガイディングシステム, 生検カテーテル の改良など, 感度が高く安全に施行できる方法 を確立するための知見を深める必要がある.

\section{3）バイオマーカーによる診断}

心サルコイドーシスの診断が困難になる場合 の原因として, バイオマーカーの感度が低いと いう点にある.516 例をエントリーした四十坊ら による大規模臨床研究によると, ACE (angiotensin converting enzyme) 阻害薬の感度は $49.8 \%$ ，リゾチームは $51.7 \%$ ，血清IgG（immunoglobulin G）は $13.8 \%$ であった7).

BNP（brain natriuretic peptide）は心不全の マーカーとして有用である. 日本心不全学会か ら早期診断に資するBNPの重要性についてステー トメントが発表されだ). 价ルコイドーシスに おいてBNPやA-type natriuretic peptide (ANP) を調べた研究によると, 心臟浸潤徴候を認めた 例ではBNPの有意な上昇がみられた。また高度 の房室ブロック, 心室性不整脈, 心不全のいず れかをきたしている例においては, BNP, ANP いずれもROC (receiver operating characteristic) 解析での AUC (area under the curve) が 90\% 以上と高く, 診断特性が優れていた ${ }^{99}$. サルコイ ドーシス患者で心臓浸潤が確認されていない例 に打いてBNPを計測することで早期診断につな がる可能性がある. 


\section{トピックス}
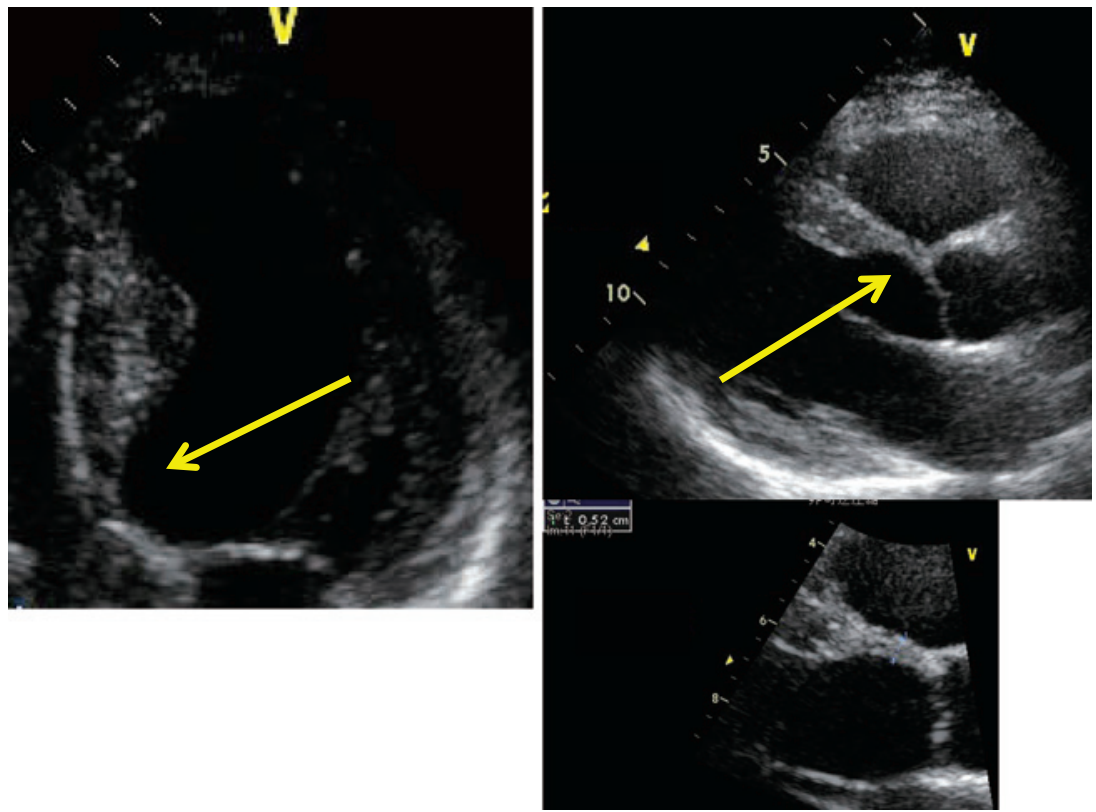

図 1. 心エコー図

左図：76 歳女性心サルコイドーシス自験例, 中隔中部の限局性肥厚と中隔基部 の菲薄化（黄色矢印部）

右図：50 歳心サルコイドーシス自験例, 基部中隔の菲薄化所見（黄色矢印部）,

計測值は $5.2 \mathrm{~mm}$ と低值を示した.

高感度トロポニンTは心筋梗塞急性期で汎用さ れるマーカーであるが，拡張型心筋症において も上昇することが報告されている．最近心サル コイドーシスで高感度トロポニンTが上昇するこ とが報告されている ${ }^{10)}$. 今後の多くの臨床例での データの蓄積が必要であろう.

\section{4) 画像診断}

（1）心エコー

従来汎用されてきたのは心エコーである。心 サルコイドーシスの好発部位は自由壁, 乳頭筋, 中隔である。病変部では非乾酪性肉芽腫の浸潤 から瘢痕形成に至り, 高輝度のエコー像として 描出される。 また局所的な肥厚の進行により非 対称性肥大を呈する。一方で瘏痕部は菲薄化し, その一部は瘤化し, また僧帽弁逆流症, 僧帽弁 逸脱が出現する。筋障害の進行によりびまん 性の壁運動低下, 左室拡大, 心膜炎による心囊
水の貯留傾向も認める ${ }^{11}$. 僧帽弁逆流症は心サル コイドーシスに多く，その機序として乳頭筋不 全, tethering ${ }^{12)}$, 進行期の左室拡大による弁輪 径拡大が原因と考えられる.

特に心室中隔基部にサルコイド病変は好発す ることが知られており ${ }^{13)}$, 同部位は限局性の菲薄 化を認める（図 1)。ただし中隔菲薄化所見の程 度は症例により差がある。菲薄化部位の壁厚の 研究では, 175 例の解析において $4 \mathrm{~mm}$ 以下に菲 薄化している例は 22 例（12.6\%）にみられた一 方で対象群 2,130 例中に 1 例もみられず, 特異度 の高い所見であるという報告がある ${ }^{14)}$.

(2) シンチグラフィー

ガリウムシンチは心蔵でも集積がみられ心サ 症の診断に有用であり, ガイドラインで主徴候 に相当する。またタリウムなどの核種を用いた 心筋SPECT (single photon emission computed 

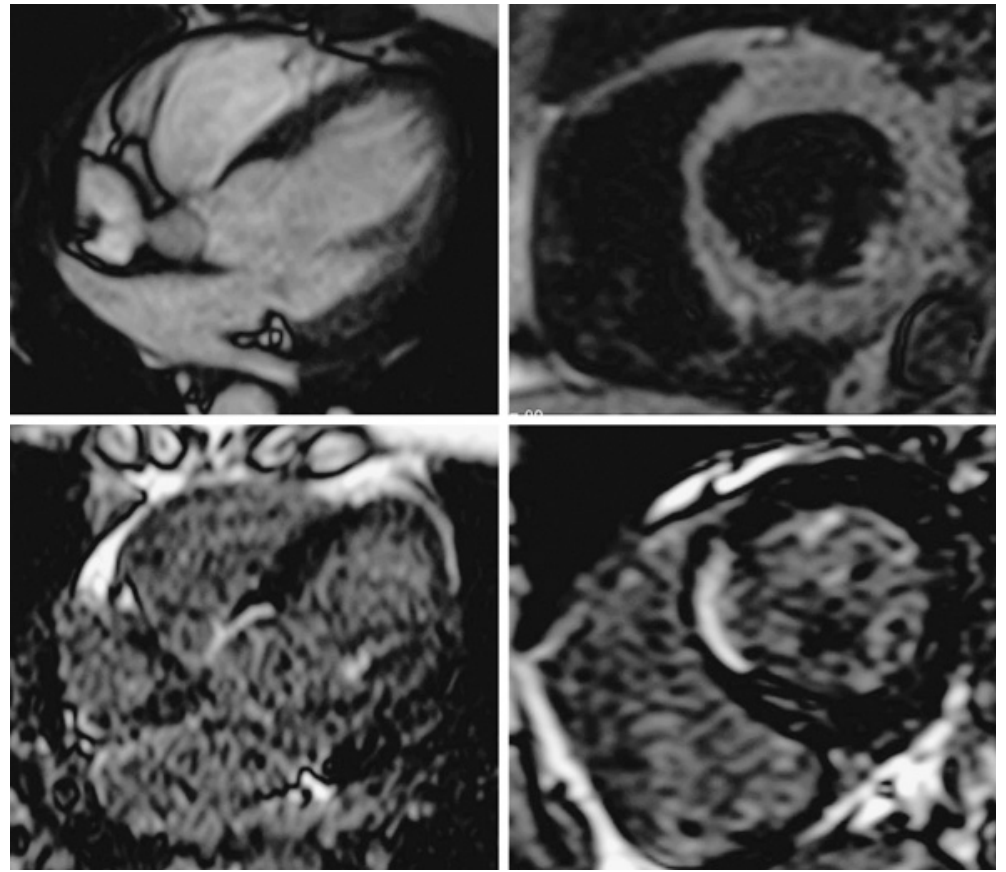

図 2. 心臟MR画像

50 歳女性（図 1 右図亡同一症例), 心サルコイドーシスの心臓MR (magnetic resonance) 画像

本症例はステロイド 60 mg隔日投与によりPVC (premature ventricular contraction）が約 6 分の 1 に減った.

上段左： cine画像 4ch, 中隔の菲薄化. 右 : T2WIBB, 中隔の菲薄化亡 高信号を認める.

下段左：4ch遅延造影所見, 中隔に陽性所見. 右 : 短軸像での遅延造影所見.

tomography)での灌流異常は副徴候に該当する. ガリウムシンチはサルコイドーシス症の診断に 汎用されているが, 最近の加藤らの多施設研究 の報告によると, 心サルコイドーシス確定診断 例 73 例のうちガリウムは心臟以外への集積は $75.8 \%$ にみられたものの，心臓は $48.5 \%$ にとど まった ${ }^{15)}$. 炎症性細胞の豊富なリンパ節と心筋で は核種の組織親和性が異なるためと思われる。

その一方でFDG(fluorodeoxyglucose)-PET(positron emission tomography)における心蔵への集 積は 66.7\%，心臓MRI (magnetic resonance imaging)の遅延造影は $67.9 \%$ とょり高頻度に認め られている15).

\section{（3）心臓MRI}

心臓MRIの遅延造影は現在のガイドラインで 副徵候に該当する.動画によるcine画像により心 筋壁形態や壁運動を評価できる. 特に, 心エコー では時に描出不良になる心尖部を含めた壁運動・ 性状の評価に優れている.またT2 weighted image black blood (T2WIBB)によりサルコイドに よる炎症機序を背景とした心筋浮腫も描出可能 である（図 2)。T2WIBBにおける浮腫はFDGPETでのFDG集積部位と一致することがあるの で重要である（図 3). 本邦で冠動脈MRA（magnetic resonance angiography) を高画質で提供で きる施設はまだ限られているが, perfusion test 


\section{トピックス}
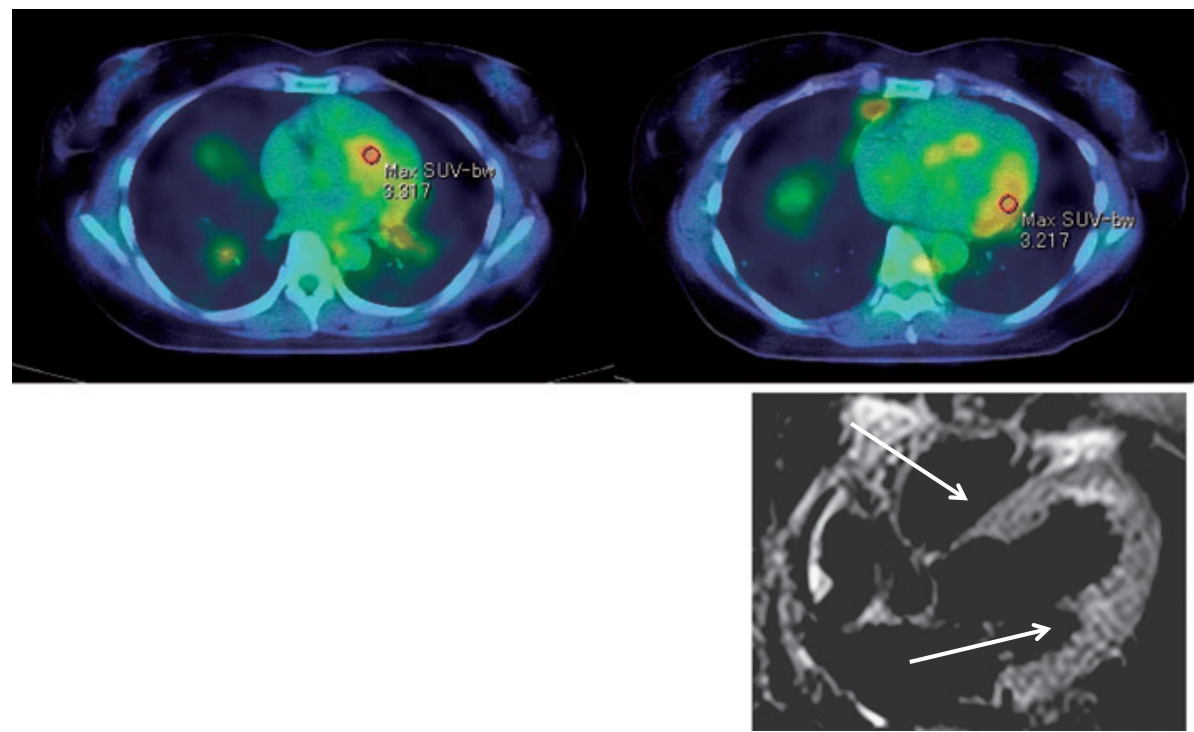

図 3. FDG-PET/CT画像

図 2 と同一症例,

上段：FDG-PET/CT画像，基部中隔と側壁に不均一なFDG集積の亢進を認める.

下段：MRのT2WIイメージング, FDG-PETと同一部位に淡い高信号を認め, 炎症性の 浮腫を認める. 心尖部内膜の高信号は血液の残存信号でアーチファクトである.

と合わせ, 心サルコイドーシスの診断に重要な 虚血性心疾患の除外が可能である.

心サルコイドーシスの遅延造影について, Mahrholdtらは, 外膜側, 後壁の心筋中層が典型 としている ${ }^{16)}$.またPatelらは後壁の心内膜側と 前壁心筋全層（transmural）という虚血性パター ンと, 後壁の心筋中層, 外膜側 (右室側), 心筋 内にpatchyに多発する非虚血パターンなど多く の所見を取り得るとしている ${ }^{17)}$. 自験例では中隔 の外膜側 (右室側) や, 菲薄化した中隔と一致 するもの（図 2), 心室瘤に一致するものを経験

\section{している.}

このように心サルコイドーシスでの遅延造影 所見は多彩に富んでいるので評価には注意が必 要である. 遅延造影はT2WIBBでの心筋浮腫や 壁運動異常部位，菲薄化した中隔に一致するこ とがあり，診断の手がかりとなることがある.

心サルコイドーシスのMR画像診断が遅れてい る理由の一つに心臓内デバイスの挿入された症
例が多いことが挙げられる。我が国では安全性 の観点から施行困難である18).

\section{(4) FDG-PET}

FDG-PETは最近心サルコイドーシスでの報告 が多く, 平成 24 年 4 月には日本でも心サルコイ ドーシスでの保険適応が認められた. 多くの研 究で心サルコイドーシスに特徽的なパターンと して心筋にfocalないし focal on diffuseの高集積が みられることが示されている19 23). 一方, 定性 的な評価の問題点を解決し, 定量評価する方法 として田原らはFDGの集積を定量的に表すSUV （standardized uptake value）を用いたCOV（変 動係数）により拡張型心筋症との鑑別が可能で あることを報告している24).

元来, FDG-PETは虚血心筋が脂肪酸ではなく 嫌気性下の糖代謝に偏り, 壞死心筋では糖代謝 が落ちることを利用して, 心筋viabilityの評価に 汎用されてきた. しかし心サルコイドーシスで の撮影原理は全く異なる. サルコイド反応によ 
り, 免疫反応により活性化された炎症細胞は代 謝が充進しているためGLUT1 (glucose transporter 1）とGLUT3 を通じてFDGが多く集積す る。しかし他臓器と一緒に撮像するような条件 では心筋全般に生理的集積がみられてしまう。 サルコイドの病変をイメージングするためには, 長時間の絶食, 低糖質食, 高脂肪食, ヘパリン 静注などが試みられている ${ }^{25 \sim 27)}$.

\section{2. 孤発性心サルコイドーシス}

最近他臓器にサルコイドを認めず，孤発性心 サルコイドーシス (isolated cardiac sarcoidosis) という疾患概念が注目されている ${ }^{28,29)}$. 孤発性心 サルコイドーシスの診断基準や疾患概念がない 時期に, 心臓に限局した心サルコイドーシスと 思われる症例について 2001 年小菅らが報告して いる ${ }^{30)}$. 当時 53 歳の女性で心尖部心室瘤を認め $30 \%$ 程のEF(ejection fraction) しかみられなかっ たが冠動脈は正常であった. ACEが軽度上昇し ており (23.4 IU $/ l$, 正常值 : 8.3〜21.4), ガリウ ムシンチで心臓にのみ集積がみられた。心筋生 検では非乾酪性類上皮肉芽腫を認めたことから， 現行の診断基準で組織診断群としての要件を満 たしている. 本症例は 10 年以上経過した現在で も他臓器所見がみられていない。孤発性心サル コイドーシスの臨床像として, いくつかの可能 性が挙げられる。1)心臟から原発して全身に波 及していく疾患の初期像をみており，その後他 臓器所見がみられる場合，2）心臓に限局した病 型が存在する，3)心蔵から原発するものの炎症 の程度などにより他蔵器に波及しない, あるい は臨床的に検知されない, 等考えられるが, 本 症例の存在はこの問題に対して示唆を与えてく れるものと考えられる.

孤発性心サルコイドーシスの診断は肉芽腫が 組織学的に確認されれば困難ではないが, 組織 所見が得られなかった場合に, どのような条件
があれば孤発性心サルコイドーシスといえるか はまだ意見の一致をみていない，その場合，先 に挙げた心臓MRIやFDG-PETが診断に有用であ る可能性がある。 今後明らかにされるべき課題 である。

孤発性心サルコイドーシスと思われる 23 歳の 症例を図 4 に供覧した。中隔の菲薄化, 左室収 縮不全 $(\mathrm{EF}=46 \%)$, 中隔の壁運動異常, 多発す るPVC, 左脚ブロックを認め, 心臓MRでは菲薄 化した中隔に一致して遅延造影を認め, 現在の ガイドラインの臨床徴候は満たす．本症例は心 筋生検の同意が得られず, 臨床所見のみしか得 られなかった. 無治療で経過観察されているが, 治療介入の必要性や有害事象の発生, 長期予後 についてさらなる精査が必要と考えられる.

\section{3. 心サルコイドーシスの治療について}

サルコイドーシスの薬物療法はステロイド薬 が第一選択となっている。これによる短期的な 改善効果は約 60〜80\% であり, 症状の軽快, 画 像所見の改善(胸部X線, 67Ga-uptake), 血液所 見 (ACE, lysozyme高值) の正常化などが認め られる ${ }^{31)}$. サルコイドーシスの多くは自然治癒 (28〜 70\%)することも認められており，このよ うな場合多くは 2 年以内に病変が消失するとさ れる31).

心サルコイドーシスでは致死性不整脈の発症 の一方で, 心筋内の肉芽腫・線維化が進行し, 壁運動が低下し心不全をきたす進行例がみられ る.薬物療法はステロイド薬が第一選択となり, ステロイドが予後を改善するというデータがあ るものの ${ }^{30}$ 報告は極めて少ない. 房室伝導障害の 改善の報告はあるが, そのほとんどに恒久的ぺー スメーカーが施行されている33).心室性不整脈の 改善については, 心機能が保たれた群ではステ ロイド投与により心室性期外収縮の回数と非持 続性心室頻拍が減少したとの報告がみられる ${ }^{34)}$. 


\section{トピックス}
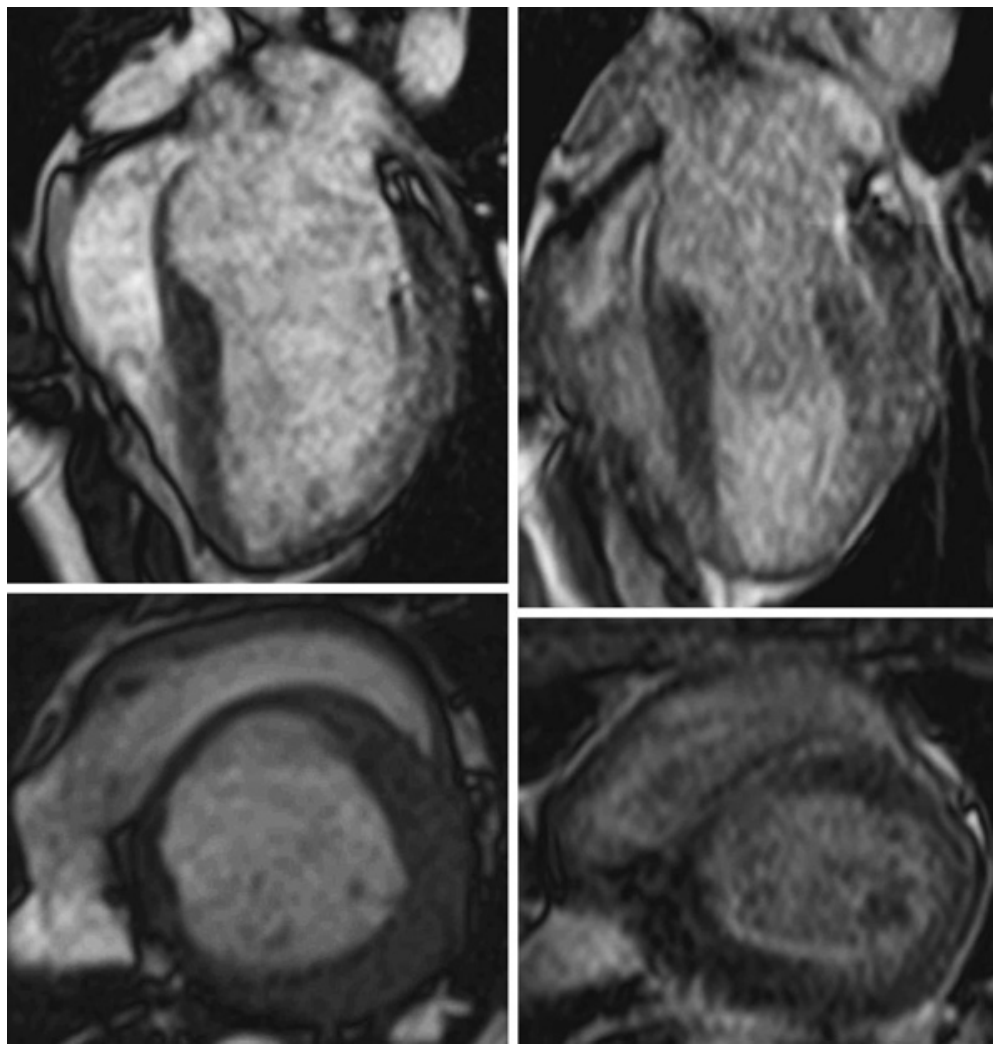

図 4. 23 歳男性, 孤発性心サルコイドーシスと考えられる症例の心臓 MR画像

上段左：cine 4ch像, 中隔の菲薄化. 右 : 遅延造影, 同部位に陽性所見 を認める.

下段左：cine 短軸像, 中隔の菲薄化. 右 : 遅延造影, 中隔中部から外膜 よりに線状陰影を認める。

自験例においてもステロイド薬導入により心室 性期外収縮の回数が著明に減少したケースを経 験している(図 1 提示症例)。一方, 画像診断か ら心サルコイドーシスが強く疑われても活動性 に乏しいと判断される症例についての治療適応 については意見の一致をみていない.

薬物療法として本症の免疫異常を標的として 免疫抑制薬を投与する報告がみられる。肺サル コイドーシスではメソトレキセートの報告が多 いが35), 心サルコイドーシスにおいて免疫抑制薬 のエビデンスはまだ構築されていない. TNF$\alpha$ (tumor necrosis factor- $\alpha$ ) 阻害薬などの生物製
剂も同様に心サ症での報告はほとんどない36).

進行した心サルコイドーシスは, 心拡大と心 室瘤やびまん性の高度の壁運動低下をきたし， 症例によっては拡張型心筋症様の所見を呈する ことがあり，末期では心不全を繰り返す。この ようなEF低值の収縮不全心においては, エビデ ンスレベルの高いカルベジロールなどの $\beta$ 遮断薬, ACE阻害薬, アンギオテンシンII受容体拮抗薬, アルドステロン拮抗薬の使用が推奨される.

非薬物治療としては, 完全房室ブロックに対 するDDDモードのペースメーカー植え込みが適 応となり，持続性心室頻拍を発症したケースで 
は二次予防として ICD (implantable cardioverter defibrillator）の適応となる ${ }^{37)}$.

心サルコイドーシスでは局所自動能が高まる ことや瘢痕器質がリエントリーを誘発しVT(ventricular tachycardia）を発症する ${ }^{38)}$. VT発症例 では非発症例より遅延電位が陽性となり, ICD 植え込み例の約半数で致死性不整脈に対する作 動が行われているという報告がある ${ }^{39)}$ ．また，

Schullerらの報告によれば, 112 例のICD治療例 の解析を行い, 36 例 $(32.1 \%)$ で適切作動が行わ れていた ${ }^{38)}$. 海外では一次予防でも心サルコイ ドーシスに対してICDが施行されることがある. 先の研究では一次予防目的で 7 割のケースがICD の適応を受け平均約 30 力月の観察期間のうちに 約 $28 \%$ のICD作動がみられたと報告している ${ }^{38)}$. しかし最新の日本循環器学会のガイドライン上 では心サルコイドーシスに対する一次予防とし てのICD治療は明確には提言されていない.

二次予防としてICDを使用したとしても, 頻回 の作動ではQOL (quality of life) の低下を惹起す る. 頻回作動を抑えるための薬物療法としてソ タロールやアミオダロン $+\beta$ 遮断薬が提唱されて いる ${ }^{40,41)}$. 心サルコイドーシスに限定してのデー 夕はまだない.

海外では心サルコイドーシスにおいても心移 植が行われ，レシピエントの予後は決して悪く ないとの報告もでている ${ }^{42}$. 日本では全身疾患で ある心サルコイドーシスには絶対適応はない． 心外病変に起因すると考えられる再発が移植心 に起こるケースが報告されているからである43). 一方で心外病変のない孤発性心サルコイドーシ スでは再発が起こらなかったという報告もある ${ }^{44)}$.

\section{まとめ}

以上, 心サルコイドーシスの診断, 治療につ いて概説した。筋生検やバイオマーカーによ る診断は感度の点で現在も課題が残っている。
一方で心臓MRIやFDG-PETは心サルコイドーシ スの診断に有用なモダリティとなっている.さ らに孤発性心サルコイドーシスに対する診断が 最近の問題点となっている. 治療面では房室ブ ロックや心室性頻脈などに対する心臟内デバイ ス治療が有効な一方で, 病勢の進行を遅らせる ような薬物治療法はまだ確立していない。今後 の課題である.

著者のCOI (conflicts of interest) 開示: 本論文発表内容に 関連して特に申告なし

\section{文献}

1）日本サルコイドーシス/肉芽腫性疾患学会, 他 : サルコイ ドーシスの診断基準と診断の手引き一2006 要約.

2) http://www.nanbyou.or.jp/upload_files/043_s.pdf

3) Uemura A, et al: Histologic diagnostic rate of cardiac sarcoidosis: evaluation of endomyocardial biopsies. Am Heart J 138 : 299-302, 1999.

4) Lannuzzi MC, et al: Medical progress:sarcoidosis. N Engl J Med 357 : 2153-2165, 2007.

5）ATS/ERS/WASOGによるサルコイドーシスに関するス テートメント

6) Sekiguchi M, et al:Cardiac sarcoidosis : diagnostic, prognostic, and therapeutic consideration. Cardiovasc drugs Ther 10 : 495-510, 1996.

7）四十坊典晴,他：類上皮細胞肉芽腫を証明したサルコイ ドーシス 516 例における各種検查所見の解析. 日竞誌 $27: 29-35,2007$.

8）血中BNPやNT-proBNP值を用いた心不全診療の留意点に ついて 日本心不全学会 http://www.asas.or.jp/jhfs/t opics/bnp201300403.html

9) Yasutake $\mathrm{H}$, et al: Detection of cardiac sarcoidosis using cardiac markers and myocardial integrated backscatter. Int J Cardiol 102 : 259-268, 2005.

10) Baba $Y$, et al : Usefulness of high-sensitive cardiac toroponin $\mathrm{T}$ for evaluating the activity of cardiac sarcoidosis. Int Heart J 53 : 287-292, 2012.

11) Abbara $\mathrm{S}$, et al: Diagnostic Imaging. Cardiovascular, AMIRSYS, 2008.

12）矢崎善一, 他：心臓サルコイドーシスの臨床像。心臟 43 (9) : 1173-1175, 2011.

13) Valantine H, et al: Sarcoidosis : a pattern of clinical and morphological presentation. Br Heart J 57 : 256-263, 1987.

14）加藤靖周, 森本紳一郎：サルコイドーシス心病変の診断 と治療. 日共会誌 $28: 15-24,2008$.

15）加藤靖周, 森本紳一郎：心臟サルコイドーシスの臨床像 に関する検討〜データシートを用いた多施設研究 : 中間 
報告. 日サ会誌 $30: 73-76,2010$.

16) Mahrholdt $\mathrm{H}$, et al : Delayed enhancement cardiovascular magnetic resonance assessment of non-ischemic cardiomyopathies. Eur H J 26 : 1461-1474, 2005.

17) Patel MR, et al: Detection of myocardial damage in patients with sarcoidosis. Circulation 120 : 1969-1977, 2009.

18) Nazarian $S$, et al : A prospective evaluation of a protocol for magnetic resonance imaging of patients with implanted cardiac devices. Ann Intern Med 155 : 415-424, 2011.

19) Nishiyama $Y$, et al : Comparative evaluation of ${ }^{18} \mathrm{~F}$-FDG PET and ${ }^{67} \mathrm{G}$ scintigraphy in patients with sarcoidosis. $\mathrm{J}$ Nucl Med 47 : 1571-1576, 2006.

20) Okumura W, et al : Usefulness of fasting 18F-FDG PET in identification of cardiac sarcoidosis. J Nucl Med 45 : 1989-1998, 2004.

21) Ishimaru $\mathrm{S}$, et al: Focal uptake on ${ }^{18} \mathrm{~F}$-fluoro-2deoxyglicose positron emission tomography images indicates cardiac involvement of sarcoidosis. Eur Heart J 26 : 1538-1543, 2005.

22) Ohira $\mathrm{H}$, et al : Myocardial imaging with ${ }^{18} \mathrm{~F}$-fluoro-2deoxyglicose positron emission tomography and magnetic resonance imaging in sarcoidosis. Eur J Nucl Med Mol Imaging 35 : 933-941, 2008.

23) Langah $\mathrm{R}$, et al : Effectiveness of prolonged fasting ${ }^{18} \mathrm{~F}$ FDG PET-CT in the detection of cardiac sarcoidosis. J Nucl Cardiol 16:801-810, 2009.

24) Tahara N, et al: Heterogenous myocardial FDG uptake and the disease activity in cardiac sarcoidosis. J Am Coll Cardiol Img 3 (12) : 1219-1228, 2010.

25）FDG-PET,PET/CT診療ガイドライン 2012 日本核医学 会 平成 24 年 9 月 http://www.jsnm.org/files/pdf/.../ fdgpet_guideline2012_120912.pdf

26) Ohira $\mathrm{H}$, et al: ${ }^{18} \mathrm{~F}$-Fluoro-2-deoxyglucose positoron emission tomography in cardiac sarcoidosis. Eur J Nucl Med Mol Imaging 38 : 1773-1783, 2011.

27）日本心臓核医学会 : 心サルコイドーシスのPET診断のガ イドライン。 日本心臓核医学会誌 15 (3) : 35-47.

28) Kandolin $\mathrm{R}$, et al : Cardiac sarcoidosis and giant cell myocarditis as causes of atrioventricular block in young and middle-aged adults. Circ Arryhythm Electrophysiol 4 : 303-309, 2011.

29) Kandolin R, et al: Diagnosing isolated cardiac sarcoidosis.
J Intern Med 270 : 461-468, 2011.

30) Kosuge $\mathrm{H}$, et al : Left ventricular apical aneurysm in cardiac sarcoidosis. Jpn Heart J 42 : 265-269, 2001.

31）サルコイドーシス治療に関する見解一2003 編集 日本 サルコイドーシス/肉芽腫性疾患学会, 他.

32) Yazaki Y, et al : Prognostic determinants of long-term survival in Japanese patients with cardiac sarcoidosis treated with prednisolone. Am J Cardiol 88 : 1006-1010, 2001.

33）加藤靖周, 森本紳一郎：心臓サルコイドーシスにおける 房室伝導障害. 日サ会誌 $31: 66-72,2011$.

34) Yodogawa K, et al : Effect of corticosteroid therapy on ventricular arrhythmias in patients with cardiac sarcoidosis. Ann Noninvasive Electrocardiol 16 (2) : 140-147, 2011.

35) Baughman RP, Lower EE : Novel therapies for sarcoidosis. Semin Resp Crit Care 28 (1) : 128-133, 2007.

36) Chatham $W:$ Rheumatic manifestation of systemic disease : sarcoidosis. Curr Opin Rheumatol 22:85-90, 2010.

37) 日本循環器学会, 他 : 不整脈の非薬物治療ガイドライン (2011 年改訂版) (2010 年度合同研究班報告).

38) Schuller J, et al: Implantable cardioverter defibrillator therapy in patients with cardiac sarcoidosis. J Cardiovasc Electrophysiol 23 : 925-929, 2012.

39）草野研吾 : 伝導障害におけるサルコイドーシスの位置づ け. 日サ会誌 $31: 63-65,2011$.

40) Connolly SJ, et al ; Optimal Pharmacological Therapy in Cardioverter Defibrillator Patients (OPTIC) Investigators: Comparison of beta-blockers, amiodarone plus beta-blockers, or sotalol for prevention of shocks from implantable cardioverter defibrillators:the OPTIC Study: a randomized trial. JAMA 295 : 165-171, 2006.

41）野上昭彦：心室不整脈に対するハイブリッド療法. 心電 図 $29: 189-199,2009$.

42) Zaidi AR, et al : Outcome of heart transplantation in patients with sarcoid cardiomyopathy. J Heart Lung Transplant 26 : 714-717, 2007.

43) Yager JEE, et al : Recurrence of cardiac sarcoidosis in a heart transplant recipient. J Heart Lung Transplant 24 : 1988-1990, 2005.

44) Chang TI, et al: Isolated cardiac sarcoidosis in heart transplantation. Transplantation Proceedings 44:903906, 2012. 